\title{
CULTURAL TOURISM IN THE FRENCH PACIFIC
}

[Received November 9th 2016; accepted March 3rd 2017 - DOI: 10.21463/shima.11.1.o8]

\section{Anne-Marie d'Hauteserre}

University of Waikato <anne-marie.d'hauteserre@waikato.ac.nz>

\begin{abstract}
History, authenticity, local culture and leisure offerings are now considered assets in local tourism development. Using a qualitative methodology, I will examine whether cultural tourism can transform the French Pacific into a sought-out tourist destination that benefits the local economy. Re-identifying the French Pacific as a cultural destination might galvanise all its stakeholders (including government agencies) to cooperate so the destination responds better to visitor expectations of the expression of indigenous culture in its localities. It would require hybrid strategies in the sense that customary practices would be commoditised. Commodification of culture raises a number of problems as it caters to fabricated needs (to fit with visitors' habitus) in order to provide the ultimate desirable experience - given that tropical island destinations are ultimately totally substitutable for tourists from developed countries. French Pacific societies have already woven multiple global links and networks, proving their resilience; can they now offer optimal and enriching encounters for both visitors and residents?
\end{abstract}

KEYWORDS: Indigenous Pacific island cultures; cultural tourism; sustainable community based development; French Pacific

\section{Introduction}

Governments are harnessing the existence of niche markets as an opportunity to deliver a 'different' product to wealthy and/or curious globetrotters in search of uncrowded and remote exotic paradises. Could marginalised indigenous groups use the cultural turn of the global economy for economic growth, even if it means commodification of their cultures (Reimer and Walter, 2013; Sofield and Tamasese, 2011)? History, local culture and leisure offerings are considered assets in local development since cultural production as it occurs within a specific place is expressive of its culture's difference. Much development, however, has come from the top and from international investors anxious to exploit the latest travel fads of voyagers. Too often, tourism development is not based on sustainability for indigenous people. Cultural enclaves developed as heterotopic destinations, for example, enable tourists to maintain their privileged position without having to negotiate a right of presence.

Using a qualitative methodology and more than twenty years of participant engagement, this article will examine whether cultural tourism can transform the French Pacific ${ }^{1}$ into

\footnotetext{
${ }^{1}$ The French Pacific includes three main territories: New Caledonia and surrounding islands, French Polynesia and Wallis and Futuna. A fourth, Clipperton Island, is not discussed in this article since no indigenous people live on it.
}

Shima <www.shimajournal.org> ISSN: 1834-6057 
a sought out tourist destination to benefit its local economy. Can it be used to give those islands an identity attractive to international visitors, since reliance on their 'French and paradisiac' attributes is less than effective? Re-identifying the French Pacific as a 'cultural' destination might galvanise all its stakeholders (including government agencies) to cooperate so the destination responds better to visitor expectations of the expression of indigenous culture in its own landscapes. Local culture(s) would require promotion and branding, ie a reorganisation of the local tangible and intangible heritage. A number of authors have asserted that although commodified - and thereby under tight control with regard to timing, duration and entertainment value - these constructed cultural tourism experiences should not be regarded as artificial (Pine and Gilmore, 1999; Schmitt, 2003; Tukker and Tischner, 2006). But what will be the consequences on the identity and feelings of belonging of the local indigenous communities as cultural tourism blurs culture with entertainment? The article examines how using reconstructed traditional culture might attract visitors who are at this time shunning the French Pacific.

The article first indicates the methodology used and its adoption of a critical social science approach to examine the various forces that influence tourism development in small island states. It then discusses the reconstruction of cultural tradition, particularly in reaction to past colonial impositions. The third section examines how cultural tourism is constructed using these traditions and its potential use as a tool of economic development. The following section discusses the resilience of indigenous island people in order to show that they are not necessarily victims of changes to their traditional culture and to illustrate how some aspects of their original culture have survived. The last section comments on potential elements that the French Pacific might use to construct itself as a cultural tourism destination in order to attract more visitors.

\section{Methodology and theoretical framework}

A qualitative methodology enables one to uncover subjective meanings that complete our understanding of the social world, which is defined out of personal and cultural experiences, not just through statistics (Bryman, 2012; Walliman, 2011; Jennings, 2011). I do not presume to speak for the indigenous residents of the French Pacific nor to have become a well-integrated insider but I bear witness on issues that concern them. I recognise that I am situated as an outsider to the indigenous society of the French Pacific but I do seek the 'becoming-ethical' of the tourism industry. My knowledge, when it has not been specifically referenced to other authors, is based on interviews and participant observation in all parts of the French Pacific over more than 25 years. A qualitative methodology recognises the plurality of interpretations possible, none of which is more valid or self-evident. On the other hand, qualitative methodology, by not seeking generalisable principles, creates challenges for direct comparisons and for repetitive hypothesis testing in other sites. However, bias exists in all forms of research, so quantitative methods do not necessarily provide more robust and rigorous results.

The data presented results from numerous visits to the islands over the past few decades, usually of 2-6 weeks but with some lasting several months). During these sojourns I have conducted interviews with residents, tourists and political as well as tourism officials and I have I observed various actions undertaken by local authorities, tourism agents, tourists and by residents (see Dewalt, 2011). These are referred to in various studies I published on these topics (see Bibiography). After familiarising myself with the data, I

\section{Shima Volume 11 Number 12017}


ordered it through coding to discover the main ideas that were developed by participants during the interviews in particular but also in relation to secondary documents (government publications, newspapers, brochures, etc.) together with my knowledge of the issues (Altinay and Paraskevas, 2008; Fairclough, 2013). Secondary documents were also analysed to reveal context, attitudes and values and to understand local actions and relations. I then linked these concepts with the existing theoretical literature.

The article draws on critical social theories to explore the dynamics of tourism development in small isolated geographical spaces and to understand how it might be implemented to become a source of local income. Critical awareness not only contributes to the empowerment of individuals and communities but it puts their voices back in the center of institutionalised public spheres. Postcolonialism is an attitude and a point of view, inscribed in a critical intervention that seeks to introduce sensitivity to the political and economic consequences of different forms of economic development. Postcolonialism is not used to indicate the end of colonialism but to elaborate alternative solutions that represent a break from the unequal relations colonial rule imposed in many areas. I have used a postcolonial theoretical framework because it questions existing relations of power (for more details see d'Hauteserre, 2004). Power is about access to resources (Chatterjee and Finger, 2014), which determines who will benefit from tourism development.

The sustainability paradigm represents the practical implementation of postcolonial theory and political economy concerns. Sustainability refers to the viability of relations between society and nature over long periods of time and encompasses issues of social justice, gender equality and political participation (Bruntdland, 1987; Kahveci et al, 2011). Other publications (Cambodia, 2008; d'Hauteserre, 2010a and 2010c; Hughes, 2004; Purcell, 2009) question whether the balance between the originally lofty goals of sustainability can be reached considering the unsustainable nature of many tourism operations around the world and the difficulty for people to change to this lifestyle paradigm. Sustainability principles are supposed to ensure a bottom-up distribution of benefits even though (or especially because) implementing laws that would support indigenisation are often considered interference with market mechanisms.

Power, position, identity and privileges (even if and especially when they are invisible) have a primary role on whether sustainability can be implemented (Church and Coles, 2006). Outside investors often have power to dictate the kind of development that will occur, its timing and its location. Epler Wood (2007) indicates the danger of tourism development left to irresponsible outside businesses or foreign investors: it leaves local/indigenous people who have limited ability to invest (even as a community) and lack knowledge of business practices with little possibility to compete. Power hierarchies also occur within small island communities. Within postcolonialism, political economy facilitates an understanding of power relations and of what matters to people, especially how they envisage tourism and which aspects to incorporate into their economy and culture. It thus supports the indigenisation of the production of destinations, ie it enables Indigenous people to have a say in the use of their resources and to reap direct benefits (Din, 1997).

French Polynesia (or 'Tahiti and its Islands', to use its touristic brand name), Wallis and Futuna and New Caledonia are all still under the colonial rule of France, even if they have acquired much autonomy, especially New Caledonia. The latter is administered by a local government and a customary council and is subdivided into three provinces,

\section{Shima Volume 11 Number 12017}


South (with a $64 \%$ Caucasian population), North (with $78 \%$ Kanak [ie indigenous residents) and the Loyalty Islands (98\% Kanak). It gained the status of Pays d'Outremer (an overseas "collectivity" with its own citizenship) following the 1998 Nouméa Accord and will vote about full independence from France in 2018 (d'Hauteserre, 2010a; Faberon and Postic, 2004). French Polynesia tried to obtain a similar status (Al Wardi and Regnault, 2011; Sem, 2000) and one of its intermittent presidents since 2004, Oscar Temaru, has asked that it be listed on the United Nations list of countries seeking independence ( $84 \%$ of its population are Polynesian). Wallis and Futuna's population is $98 \%$ Polynesian and requested the French government that it remain a Territoire d'Outre-Mer (a French external territory) - with minimal autonomy (for more details see d'Hauteserre, 2015b; d'Hauteserre, 2010c). As many Wallisians and Futunans today live in New Caledonia as are still left in the territory. All three areas benefit from large subsidies from France: French Polynesia as compensation for past nuclear testing; New Caledonia as a condition of its remaining French and as a result of nickel revenues; Wallis and Futuna, as a dependency of the French state. Unfortunately these subsidies are unevenly distributed so the majority of the indigenous population lives under the poverty line. The French state and the local governments believe that tourism would provide income for at least some of these people.

\title{
Cultural tradition and its construction
}

Cultural tourism depends on at least a modicum of traditions that are either extant or else have been resurrected, even if amidst accusations of inauthentic fabrication. Reassertion of tradition has been used to counter colonial legacies but also to legitimate political claims. There has also been much emphasis on how cultural revivals prove that cultures are resilient and can survive colonisation. Culture is living: it is constantly in flux, reinventing itself through cognitive, habitual and performative practices. No culture is a perfect, complete product. Relics of colonialism (not just abroad) still abound and continue to impose 'modernity', erasing others, as in the doctrine of terra nullius, ${ }^{2}$ even today for some ecotourism projects (Cambodia, 2008; Wheat, 2002). They also render non-modern ways inferior, non-progressive, static. Such representation is sustained by an imaginary, ie an interrelated set of signs that present themselves in every instance as an "indisputable and undisputed meaning" (Mbembe, 2001: 175). The past is reconstructed on the basis of those items that have been retained in the present. The point, though, is not to preclude the past. Nor is it to ignore that there has been some cultural and historical continuity, despite colonial onslaughts, due to the capacity of people to integrate experiences into coherent forms.

Hybridised cultures, as they have developed following colonisation, are claimed to have lost authenticity and, thereby, their authority, while primitivism is conceived of as able to redress past indigenous marginalisation. Elementariness or primitiveness describes a world incomplete or adhering to strange (for example shamanist) practices and thus impenetrable, ie outright incompossible with modernity. According to Lyotard (1988), indigenous peoples' identities are radically inaccessible, they are not just an inchoate opposite. They are different, irrepresentable (d'Hauteserre, 2010b). However, there is no

\footnotetext{
${ }^{2}$ A Latin term used to describe a territory that has never (previously) been subject to state sovereignty. This term (and concept) was used as a justification for imperial annexation of indigenous lands.
}

\author{
Shima Volume 11 Number 12017 \\ $-58-$
}


primitively 'pure' and thus 'authentic' native tradition today. Any form of indigenous cultural revival needs to be acutely aware of rupture from its original social and religious context (Durban, 2005). Re-enacting pre-European practices would require the adoption of political and legal forms that existed then (or close approximations) in order for those elements that are pursued today to become an integral part of a revived culture or of an authentic return to roots. Very little remains of traditional or indigenous cultures in the French Pacific since lines of oral transmission have been broken, those who had the knowledge never wrote it down and physical elements, made mostly of wood or natural fibres, have long since disappeared (participant observation; d'Hauteserre, 2008a and 2008b). How can 'authenticity' be determined here? But who is calling for 'authentic' cultural expressions? It would depend on what one seeks in 'authentic' cultures.

The process of colonisation and imperialism has rendered it impossible to return to a pure, untainted space of authentic experience or thought from which the West can be eliminated. The true question is not whether we are witnessing a conflict between tradition or archaism and modernity but how indigenous Pacific communities can be empowered. The need to attract visitors may not correspond with ensuring that painful truths are addressed or that the protagonists' own story is told. It may lead to moulding history to specific audiences, since the point is not so much to learn - as in educate - but more for feel-good or exhibitionist reasons. Indigenous elites have encouraged traditional cultures, to support local pride but Hau'ofa has provided a severe critique of this: "The privileged can afford to tell the poor to preserve their traditions; the privileged only talk about it from a position that enables them to select and determine the practices they will impose on others" (1987:4) while they conveniently forget or obfuscate economic conditions and social cleavages. In French Polynesia, Gaston Flosse (Head of local government 1996-2004 and intermittently since) wanted "Tahitian" cultural practices to be adopted by all, when different kinds exist through the territory and when social cleavages were worsening (personal observation; Al Wardi and Regnault, 2011). For others, the past may be important to the construction of the future, but it is vital that attention remains turned to the future:

the return to tradition is a myth ... No people have ever done it. I see the search for identity, for a model, as being ahead of us, never in the past - it's a permanent process of renewal. I feel that what we are striving for is to bring as much as we can of our past and our culture into constructing the personal and social models we want to guide the building of our polity... Our identity is ahead of us. (Tjibaou, 1996: 185).

\section{Constructing cultural tourism}

Tourism has followed cultural economic trends by developing various forms of cultural and heritage destinations that provide new kinds of natural and cultural 'experiences'. Experience creation is a critical element in cultural tourism as tourism sells strong social imaginaries of dream vacations and takes dreams and myths to inscribe them onto places, transforming them into desired destinations. Cultural tourism has been defined as travel for the purpose of studying the way of life in the area being visited or, more truthfully, as using a country or region's culture for the production of ludic space (for leisure and amusement) (Ducros and McKercher, 2015; Timothy, 2007; Weaver 2003). Cultural tourism developed by outside/foreign capital does not and was never intended to promote indigenous characteristics or preferences even when it showcases the

\section{Shima Volume 11 Number 12017}


traditions of indigenous cultural communities (such as festivals and rituals). Cultural tourism provides the opportunity to engage in something different so it can position communities competitively on the international market. Culture and its artefacts can thus be commoditised as tools for the economic development of an area.

Demand is increasing for islands with 'primitive' cultures because tourists perceive these as more 'authentic'. Authenticity is one of the key words in present-day discussions of cultural heritage. One can also dispute the contemporary authenticity and place of indigenous cultures as they have become commodified for tourism. However, defining what is and what is not authentic raises a number of serious issues, and there is no common consensus. Authenticity is often based on assumptions about the process of non-technological knowledge or fabrication. Cheer, Reeves and Laing (2013) recorded that indigenous residents of Vanuatu kept honouring their traditions while they realised that tourism would bring change. Change was tolerable, though, because it brought economic returns. It is a reminder that tourism is an economic, monetary activity. Definitions of authenticity are thus contested by different interests and are variable, even locally. Daniel asserts that, "authenticity prevails when the individual is affected/touched... it relies heavily on the desire for 'authentic' experiences of the performer" ((1996: 783 - also see Diamond, 2008).

Tourist destinations are constructed by those who have power and who then control content and meaning according to specific socio-cultural dynamics. As Shurmer-Smith and Hannan have contended: "we want to show that sites are but cultural constructions and can thus appear and disappear, change size and characteristics, depending on how they were constructed" (1994: 13). Peripheries are constructed myths promoted by the center. They survive only as long as they are marginalised (Hardt and Negri, 200o; Jokolevitch, 2007). Indigenous presence is hidden behind policies that transform indigenous space into aestheticised spatiality or novelty for the tourist gaze. Such construction "edits the world", as Heckman surmises (2008). Imagination precedes most journeys, moulding tourist preconceptions and expectations. A trope or representation, of indigenous peoples for several centuries was of vanishing races, dying remnants of once vigorous and populous tribes. Such discourses are taken up by private as well as public tourism agencies because they are one of the most successful tropes in tourism marketing. Paradise attracts because it is ephemeral.

Creating spaces for tourist performance provokes a change in the social practices of the local community: "because tourism is not always as innocuous and benevolent as destination elites or industry leaders claim it to be, there is a clear need for careful management and planning in the realm of cultural tourism" (Timothy, 2007: xi). Tourists, however, often seek the 'back stage' that they believe contains tradition but which is actually inhabited by modern ways of life (personal observations in the French Pacific). The culture of display (exhibitions, staging for tourists) is shaped by complex relations of colonisation, modernity and neo-colonialism. Promotional campaigns resort to belittling images of indigenous people that emphasise their difference because of their 'natural' state and their primitiveness (d'Hauteserre, 2011; Olsen, 2008). For western consumers, remote islands have become accessible products for their entertainment (King and Connell, 1999) or have islanders managed to dynamically reconfigure their social organisation and transform their understanding of their communities when dealing with capitalist consumption? 


\section{Local resilience}

Can the islands of the French Pacific and their indigenous residents truly offer optimal and resilient encounters in the form of more fecund host-guest exchanges or will they become empty stages without any audience after having first turned their back on local needs? What will be the consequences on the identity and feelings of belonging of the local indigenous community? Indigenous people did not just accidentally beach on the islands ocean currents led them to (Kirch, 1986; Rolett, 1996). They maintained the identity they had created, not from a specific territory (which only exists in colonial decrees) but through multiple networks in which islands are the nodes that nourish the numerous geographic and social ties they still maintain. ${ }^{3}$ Pacific migrants never severed physical, social or even emotional ties with the islands they came from. Movement was and remains a widespread cultural theme of great significance in the Pacific (Hau'ofa, 1994; Teiawa, 2001). One must not underestimate their resilience and vitality. From the beginning of the colonial era, indigenous peoples adapted to flows of information, products and visitors, declaring that on the "basis of the frequency of European visits, [their islands] must be the most beautiful of all living places in the world" (Newbury, 1980: 78). Campbell added that "Polynesian history shows unremitting calculation and determination to seize whatever advantages circumstances offered" (1982: 71).

The indigenous people of the Pacific islands never considered that they led isolated, marginal or even precarious lives. These societies have woven multiple global links and networks: for religious reunions or pilgrimages; for military draft or commercial purposes; for jobs; while all maintain(ed) ties with those who stayed in the islands (d'Hauteserre, 2008b). Colonisation itself has left deep changes, such as massive movements of people who brought with them a different culture and potential conflicts. For example, more Wallisians and Futunans live outside of the territory than in it. Many Chinese, Indonesians and Kabyls live in Tahiti or New Caledonia, and many Indians in Fiji. All indigenous islanders believe that they can participate in the global economy in order to gain some economic benefits, contrarily to Kerdilès, who asserted that "when one has learned to do without the superfluous, why become once more its slave" (1998: 53). Globalisation, which involves spatial reorganisation and economic restructuration, can also signal a qualitative reorganisation. The residents of the French Pacific have shown great resilience over several centuries, against waves of conquests and the effect of cyclones. In the Marquesas Islands, after having dropped from 43,000 in 1820 to 2000 in 1924, the population had bounced back to 8700 in 2004 (Institut territorial, 2008).

The interactions between groups described above have resulted from active participants, each with their own agenda, even if, as Prakash asserts, the subaltern can never be autonomous (1994: 1480). Alternative 'modernities' do exist (Rofel, 1996). Today, ties between Pacific people are maintained via air and satellite links. Local communities are not considered here as archaically traditional. The social and economic order in the Pacific is constantly reconstructed and transformed as local communities are dynamically reconfigured in their encounter(s) with capitalism. The modernisation that tourists introduce is only one of the numerous interrelations that these peoples have survived (d'Hauteserre, 2008a and 2008b). The notion that tourism would modernise indigenous people serves to erase their identity as dynamic agents in various networks. Traditional cultural and social capitals have supported their adaptation (Baldacchino,

\footnotetext{
${ }^{3}$ One of which is materialised by the burying of the umbilical cord (Panoff, 1970).
} 
2005; Skelton, 2007). Polynesian and Melanesian agency and cultures are born of history and geography evolved on these islands, where life has certainly been difficult, but not fragile, for more than a millennium.

Residents of the French Pacific who practice traditional activities (generally limited to art forms such as dance, music, sculpture, tattoos and strength activities, such as carrying heavy loads, lifting stones, throwing spears etc.) remain proud of them. Marguerite Laï narrates a visit to East Berlin before the fall of the wall: "It was such a sad, grey city but when the toere [an instrument that gives the dance rhythm] resounded, a people rushed to the performance. They were curious but also admired this exciting form of dance" (interview, 2012). But rupture with the past has been significant and many islanders appreciate a modern lifestyle, like this migrant from the Tuamotu Islands then living in Tahiti: "I like air-conditioning and the comforts of Tahiti, as well as my job" (interview, 2003). Most migrants from the outer archipelagos of French Polynesia who settle in Tahiti had no intention of returning to their original islands because subsistence living is too harsh to go back to (interviews, 2003; Schaeffer, 2001).

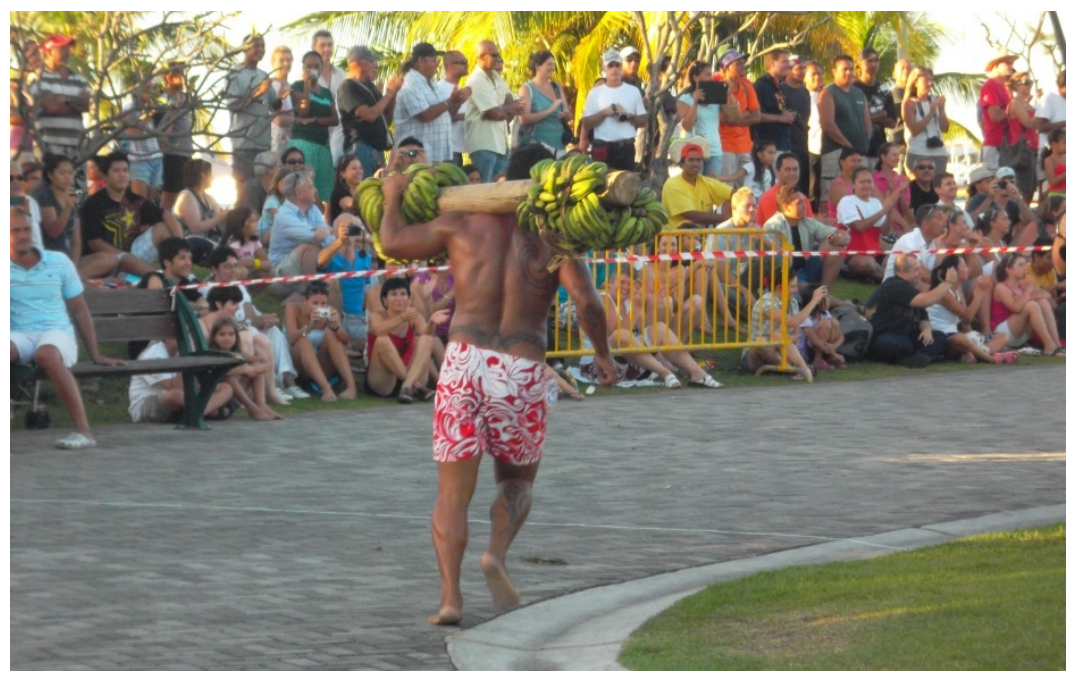

Figure 1 - Strength competition during the Heiva. Running with a heavy load; athletes compete in different categories, determined by the weight of the load (author's photo, 2012).

\title{
Creating sustainable cultural tourism
}

In order for tourism to become a sustainable activity that benefits local people, especially in small (island) states, it must be co-produced by local residents on their terms. Positive planning and implementation of tourism policies are key issues in terms of enforcing land development plans, making cultural and natural heritage relevant, implicating communities and mainstreaming environment issues in policy-making. A gap though still exists between the original discourse about sustainability and its implementation in tourism development because the former remains embedded in its capitalist roots. This discourse often obfuscates the lack of implementation of the principles it seems to advocate. Foreign owned 4-5 star resorts in New Caledonia or Tahiti exemplify this form

\author{
Shima Volume 11 Number 12017
}

-62 - 
of foreign capitalist investment-led tourism development. Intrusions by global tourism operators or hotel multinationals require heavy infrastructure and superstructure. Such intrusions are generally ill-adapted and often ill-conceived for small island landscapes and social formations. They offer profits for their international investors only. Local residents only gain a few jobs if the venture is successful. In the Cook Islands, Uvea (New Caledonia) and Tahiti several derelict structures attest to their lack of success. These ruins also mar the landscape for future visitors.

Employment by non-indigenous tourism companies is the least favourable form of indigenous tourism development for the community, even when responsible tour companies hire local guides, since it means minimal indigenous participation in the development of the product so they are left to "feel as little more than artifacts of the culture" (Diamond, 2008: 102). Some indigenous groups receive lease fees for ventures located on their traditional lands but do/have not participate/d in their development, as in the Ile des Pins and in Uvea but also on the Grande Terre of New Caledonia when Club Med rented land at Hienghène. Cultural displays must respect local communities and present cultural specificities (rather than generically primitive ones) or recognise that culture and its material manifestations can evolve without reducing their authenticity. Social and political processes limit the capacity of local residents to negotiate with private operators and government agencies. Dominant local elites often gain most economic benefits. Indigenous tourism ventures face the same issues of product development, marketing competition, quality control, training and profitability - as well as limited visibility and accessibility - faced by other local ecotourism businesses.

When cultural tourism projects are carried out without the involvement of local actors, it reduces their sustainability since no one oversees whether they are just used to enable a few to profit from difference. Co-production of cultural destinations (mostly between indigenous producers and tourists) seeks to problematise representations of the world that have enabled a hierarchically ordered placing of cultures based in part on their presumed authenticity (read: their incapacity to evolve). Critical awareness provided by post-colonial co-production contributes to processes of self-understanding and empowerment of individuals and communities with greater likelihood of implementation of sustainable practices. The tourism destination is the most interested stakeholder in sustainability, ie in yield management and quality, rather than in numbers of potential visitors. French Pacific authorities have yet to implement these principles.

\section{Cultural tourism in the French Pacific}

The islands of the French Pacific might be promoted as paradise on earth but not enough people seem to want to experience it since numbers of tourists have been steady or declining over the recent past while numbers of visits to other Pacific islands are increasing (d'Hauteserre, 2015a). Part of the problem may be that locals are not engaging in improving the attraction of their locations (Gay, 2009). The local government also maintains a (misplaced) belief that the territory has an irresistible appeal for tourists (interviews at the tourism office, 2012). For instance, Tahiti Tourisme in its North American promotions emphasises that Tahiti is "a destination so exotic, it exists only in one's dreams." Festivals or special events have sprung up in the island Pacific, especially in Melanesia, which could be promoted as cultural tourism. The most famous is the 
Festival of Pacific Arts held every four years. Unfortunately its infrequency and its organisation in a different venue each time make it a difficult target for tourism promotion. It could, however, be attractive for tourists who already know the Pacific. Festivals of Melanesian art occur every 2 years and in a reduced number of locations so they might be easier for tourists to access.

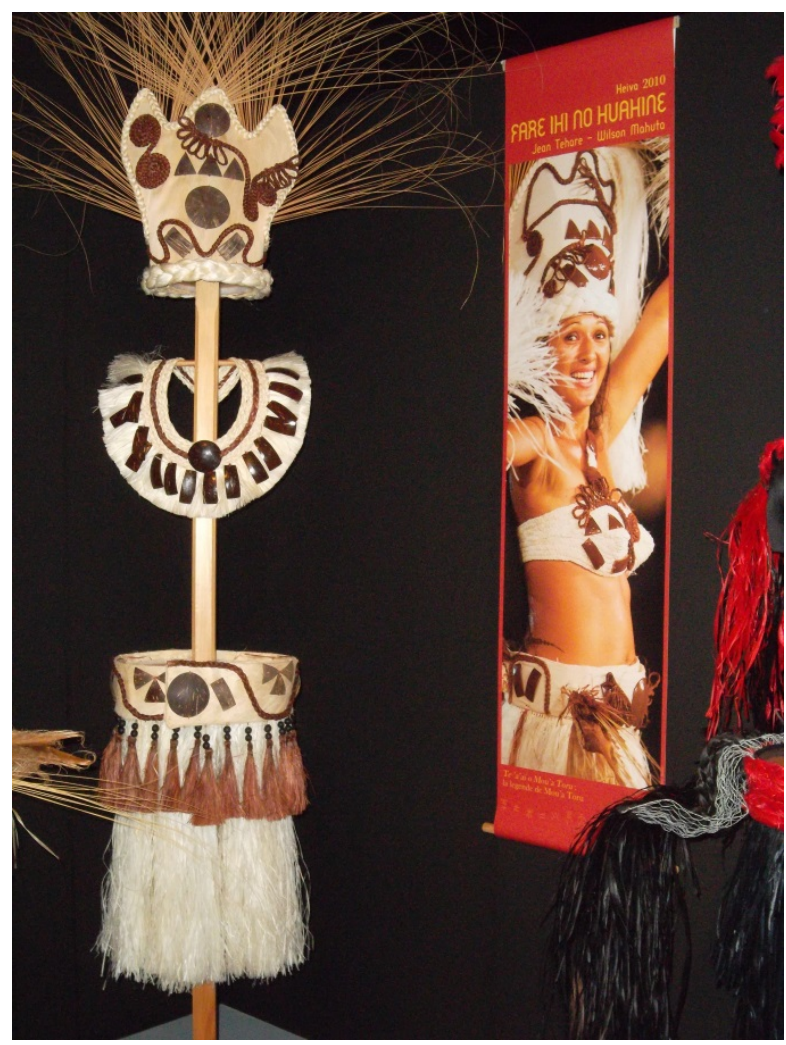

Figure 2 - Dance costumes in Tahiti. The men's costume is on the stand, the women's is on the poster. These costumes are displayed in the Museum in Punauuia, Tahiti. They come from dancing groups who participated in a Heiva competition. (author's photo, 2012)

Economically, territories of the French Pacific appear to be very different from other Pacific island countries. Poverty seems to be less prevalent than elsewhere in the Pacific (Abbott and Pollard, 2005) and there is an expectation of continued financial assistance, with most residents convinced that the territories are major strategic and emotional assets for France (Mallatrait, 2009). Subsidies from France, revenues from nickel mining or actions by the local governments, however, have benefited a minority of the population in the French Pacific, so many do suffer from poverty ( $28 \%$ are below the poverty level in French Polynesia and 60\% practice subsistence living in Wallis and Futuna), in spite of a high GDP per capita. The very comfortable situation of most politicians in the French Pacific has hindered efficient policy making with regard to economic development that benefits the majority of the people (Al Wardi and Regnault, 2011).

\section{Shima Volume 11 Number 12017}

-64 - 
For the French Pacific, tourism is not something to grab at by chance; it is a necessary economic development option "because it provides jobs for the unskilled; it is adapted to island residents [and] would reduce emigration flows and the unemployment that often follows" (from Mission, 2000: 87, about the Tuamotu islands). Can cultural tourism be used to give those territories an identity attractive to international tourists? It would require the creation of quality, original, and competitive products. Development of arts and crafts can help the development of cultural tourism. They offer an exit for surplus production of some islands (eg material for mores from Palau; mother of pearl and other types of shells from the Tuamotu islands). They also support local culture as they help transmit traditional knowledge and maintain social cohesion following exchanges between generations. They also enable income generation without residents leaving their islands. Arts and crafts provide particular benefits when products are unique in the souvenir market and when there is a tie-in with local attractions. Focusing on reidentifying these islands as 'cultural' destinations might galvanise all their stakeholders (including government agencies) to cooperate to address visitor expectations. Today, too many organisations are responsible for the promotion of tourism in New Caledonia and Tahiti and its Islands while there is none addressed to Wallis and Futuna.

a. Tahiti and its Islands

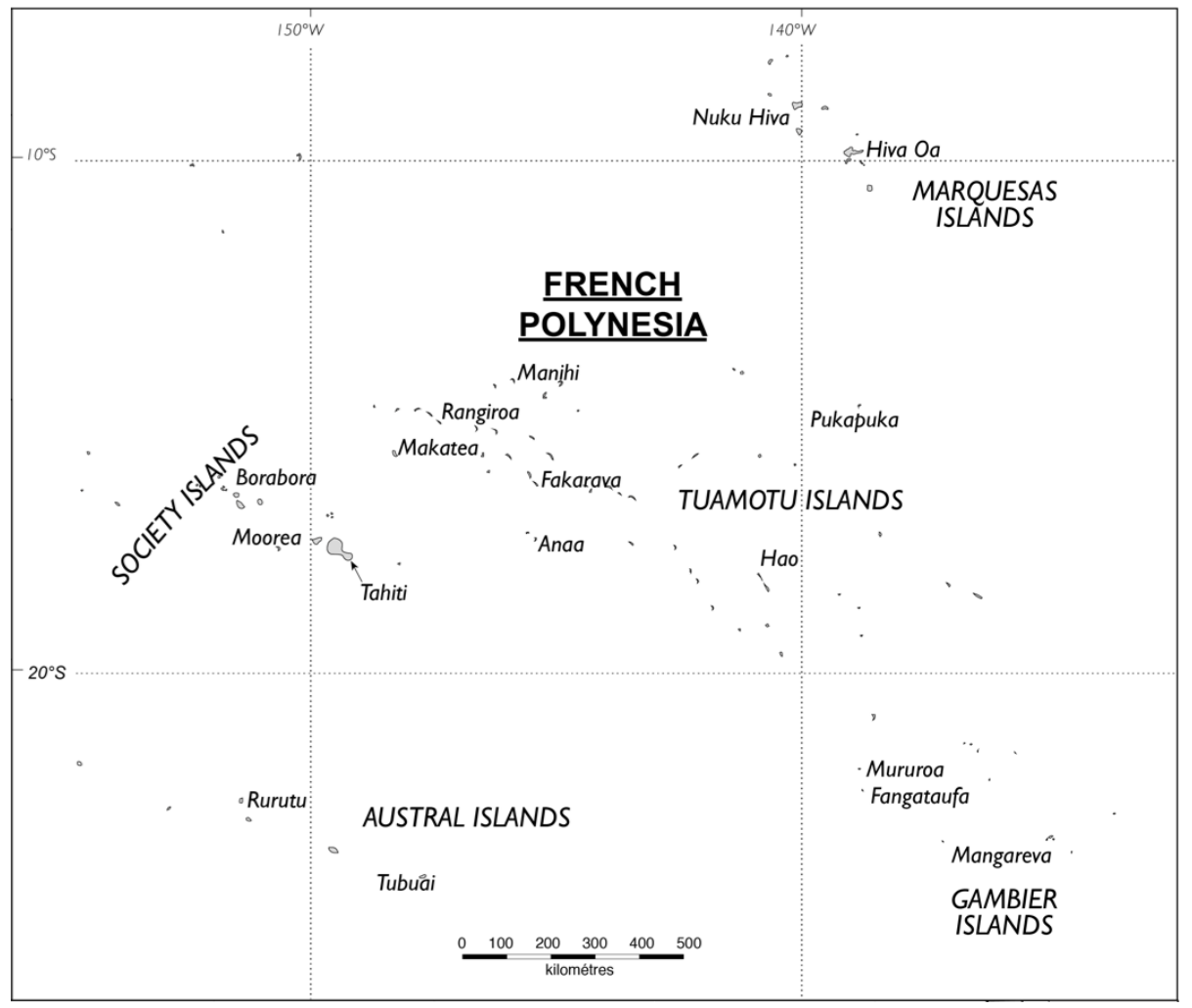

Figure 3 - Map of French Polynesia (by Max Oulton, Cartographer, University of Waikato, 2017)

\author{
Shima Volume 11 Number 12017 \\ -65 -
}


d'Hauteserre: Cultural Tourism in the Pacific

In French Polynesia, reliance on myths of paradise and the sensual vahine no longer attract sufficient numbers of tourists (with a decline from 218,241 tourists in 2007 to 168,978 in 2012). A hotel owner in Bora Bora in French Polynesia innovated with over the water bungalows but it was soon copied everywhere else in the tropical world; much of the content of the 'paradise' dream has also been used elsewhere (d'Hauteserre, 2005). Even amongst Pacific islands, Fiji and Guam are way more successful. Could Heiva Tahiti, the 120 year-old and oldest cultural festival in the Island Pacific, together with other festivals that celebrate traditional Polynesian culture, make Tahiti and its Islands a sought out tourist destination, thereby helping the local economy? Is 'Ori Tahiti (traditional dance of Tahiti) a specificity of French Polynesia that would make it particularly attractive for tourists who seek desirability in rarity? In June 1985, following a change in governance that led to greater autonomy for the territory (in 1984), July festivities, until then centered on Bastille Day, were re-baptised Heiva I Tahiti and scheduled over the last 2 weeks of June, so all islanders could seize the opportunity to renew ties with their cultural roots that would give a more Polynesian base to this event. The Heiva Tahiti, a community based event, takes place in Tahiti's main urban area, which contains more than $50 \%$ of all of the population of French Polynesia, so it is closely followed by local people and its performances are generally wellattended. The majority of the public for the Heiva or the Hura Taiparu are currently local residents but there is capacity to welcome tourist attendance.

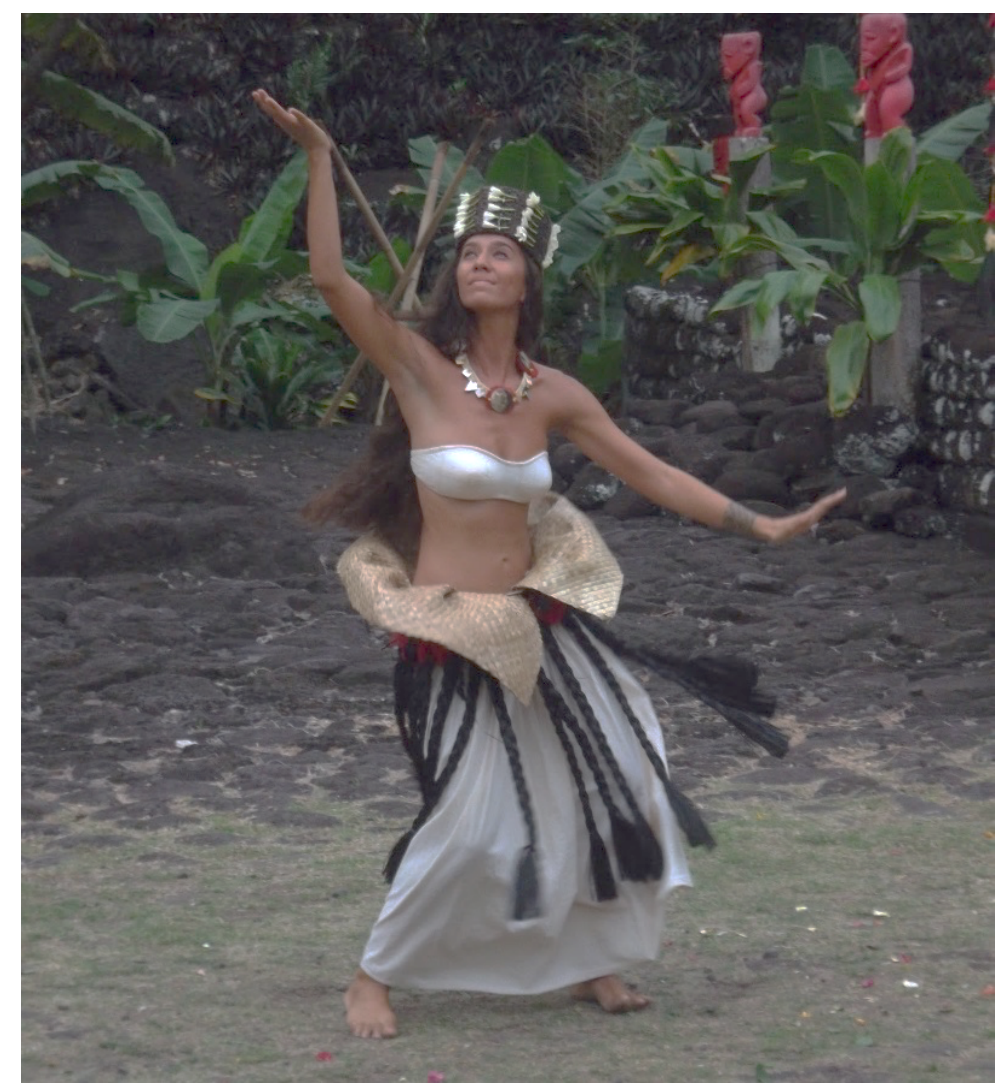

Figure 4 - Dancing at a reconstructed ceremony on a Tahitian marae (author's photo, 2012).

\section{Shima Volume 11 Number 12017}

-66 - 
The Heiva only includes traditional activities: entertainment, physical exercise, music and dance. It maintains traditional knowledge through the use of local products to create costumes and to choreograph dances (although the material for the mores is imported from Palau - interview with dance group leaders, 2012). It requires continued training in traditional physical activities, though some are linked to more recent introductions such as the colonial coconut. The dance competition at the Heiva is hotly contested because the winner is honoured and respected, similarly to the victor in a sports or combat contest. The spectacle is rewarded at the Heiva, rather than its similitude to ancient practices, in spite of the event's insistence that assessment is based on tradition. The Festival has never been promoted to tourists, which would require more coherent governance of the event.

Another festival that could enrich the cultural offerings of Tahiti, the Hura Taiparu, which takes place in December, welcomes small groups (10 to 20 dancers) and supports creative innovation but exists only for dance groups. It does not compete with or refute the more traditional forms required by the jury of the Heiva. Many groups use it to test their choreographies before competing at the Heiva. This year the competition included dance groups that have developed 'Ori Tahiti in countries far from Tahiti and its Islands, some of which claimed first or second prize in several categories (personal observation, 2016). Some local residents resent the appropriation of Tahitian dancing by foreigners given that they could be recruited as promoters of Polynesian islands when they return home. Marguerite Lai has organised the recreation of ceremonies on marae, which need more and better promotion.

\section{b. New Caledonia}

In the Northern Province of New Caledonia, where more than $70 \%$ of the population is Kanak, the government encourages Kanak cultural tourism development without transforming it into a folkloric show and the government is currently calling for motivated entrepreneurs who have projects in mind. Women are often the first to respond but customary practice tends to prevent them from owning or having access to land, the basis for welcoming cultural tourists. On the main island of New Caledonia, visitors have to go out of their way if they seek contact with Melanesians as the majority of the hotels are in Nouméa or exist as enclaves in the Northern and Loyalty Island Provinces. Few international visitors step outside of those enclaves. Domestic visitor numbers increased when both Provinces (Northern and Loyalty Islands) started offering thematic weekends with overnight stays in local structures: with accommodation in traditional houses next to modern sanitary facilities that can sleep two to eight persons. The Loyalty Islands are more oriented to natural attractions while cultural attractions are more prominent on the mainland. In both cases other cultural activities are also offered for entertainment. Many Melanesian forms of art have also been regrouped in the Tjibaou Cultural Centre in the capital, Nouméa. It attracts around 100,00o visitors yearly and its exhibits and activities could induce international tourists to visit other areas for more personal encounters with their creators.

A successful example of a cultural encounter in a French Melanesian landscape is the Eiao cruise stop in Lifou Island (Loyalty Island Province). Members of the local Kanak tribe prepare excursions, local products and souvenirs that an increasing number of cruisers seek. It is special because the preceding attempt at Poum (north of the main island) had been a complete flop: cruise visitors strolled for just a few minutes amongst

Shima Volume 11 Number 12017

-67 - 
stands whose owners hid in their dark recesses. There was no cultural show and visitors often came without money since they were then moved to a private island for lunch. Another company offered to use the stop if cruises were welcomed by nude warriors, and the government immediately closed the stop (interview, 2009). The Eiao stop sells a more authentic encounter with the local people and their culture, and a very different picture from the one diffused by the Tourism Office of the Southern Province (see d'Hauteserre, 2011). Locals offer excursions to points of interest around the island. They cooperate with the (local) founder of a restaurant specialising in local products, including coconut crabs, which have disappeared from most of the French Pacific but still exist in Lifou and Mare.

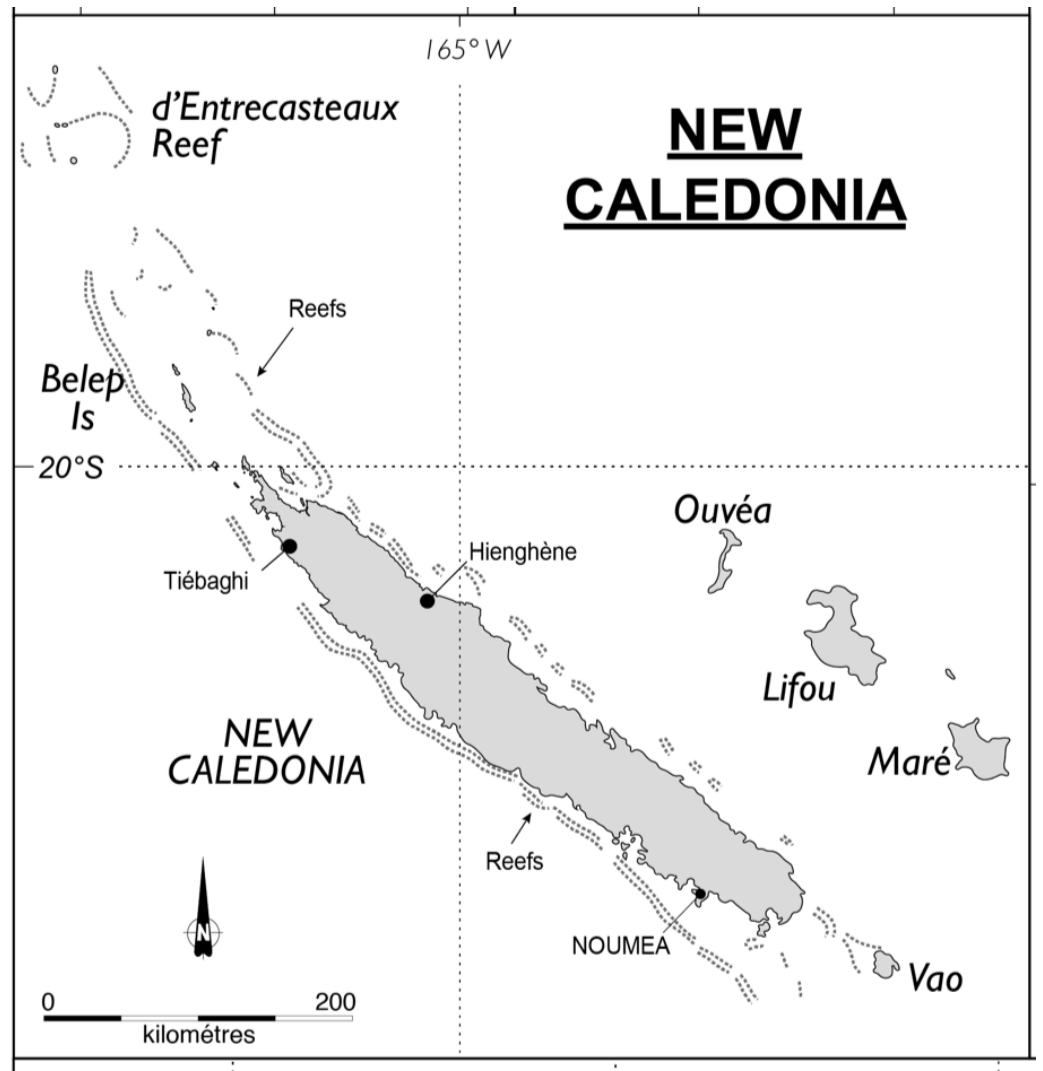

Figure 5 - map of New Caledonia (by Max Oulton, Cartographer, University of Waikato, 2017)

Kanak culture and customary practices were recognised in the French Constitution following the Matignon Accord of 1988 and the Nouméa Accord of 1998, as per specific legal provisions (Faberon and Postic, 2004). Kanaks are protected from outside investors on their customary lands, since permission must be obtained from all members of the tribe, who can regain possession of the land at any time. The Eiao cruise stop is a community based initiative. The local chief came up with the idea of offering the stop in the turquoise waters close to the southern part of Lifou island. Discussions started in 1978 and the first boat was welcomed in July 1995. Only five ships came in 1995, one 
hundred in 2013. Australian and Japanese companies want to bring more ships but the Kanak residents do not want to become overwhelmed. This tribe created the Wedr dance group to welcome cruise visitors and is also in great demand in the rest of New Caledonia and overseas (interview of local officials, 2015).

The cruise stop area was in need of refurbishment when I visited in 2015 but it was also due to be enlarged in order to receive and increasing number of cruiser visitors within several traditional houses and with a larger parking area for new buses to take people on excursions. The expansion was foreshadowed in 2010 but required funding and the customary act was finally signed in October 2014. The chief and other local officials are aware that growth is attractive but that its effects must be carefully monitored. Benefits are redistributed throughout the community by rotation, which has become more frequent with the increasing number of ships. Custom requires sharing but this way all families participate as well as more and more members of each family, so there is less pressure for 'customary sharing' which inhibits much entrepreneurship (interviews with local officials, 2006-2015). Sharing with the rest of the island community (the local tribe of Wedr occupies only one third of the island) seems to have less appeal for the Wedr but was one of the conditions of the $70 \%$ provincial government loan to enlarge and improve. Despite this, the expanded sharing remained an issue in 2015 (interviews with local officials, 2015). ${ }^{4}$

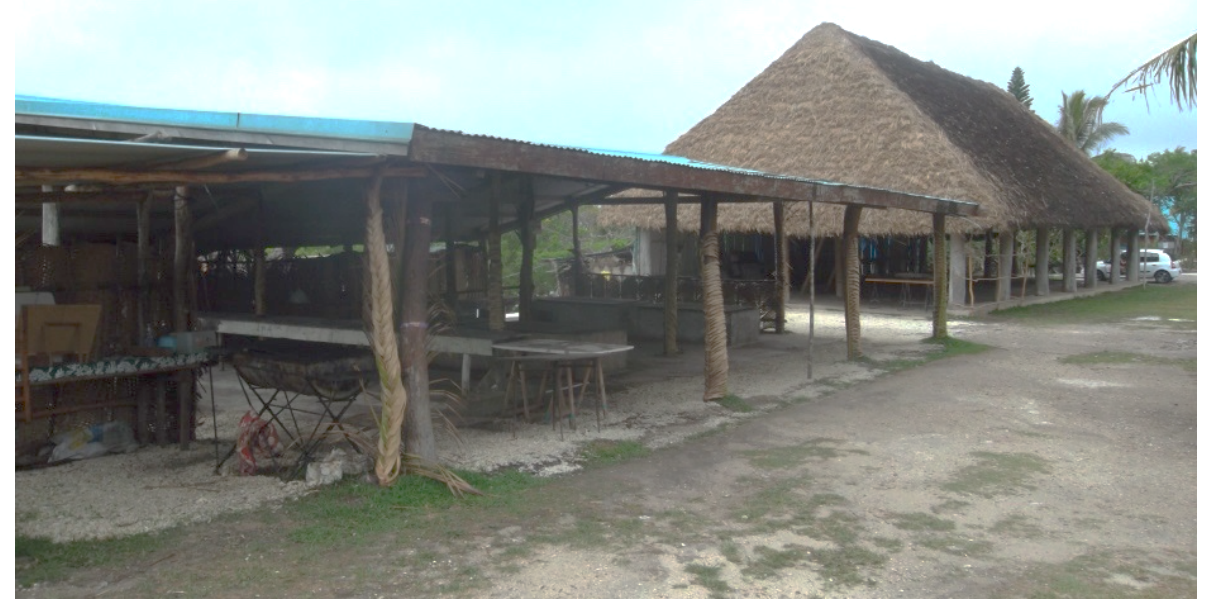

Figure 6 - Structures that welcome the passengers at Eiao and where various indigenous (only) entrepreneurs from the Wedr tribe offer tours and souvenirs (author's photo, 2015).

\title{
c. Wallis and Futuna
}

A relatively well preserved Polynesian culture on very small remote islands is not the only asset of Wallis and Futuna. Even older colonisers than France have left relics that have been restored and can be visited (like the Tongan forts of the 1600 in Wallis;

\footnotetext{
${ }^{4}$ For other possible attractions in New Caledonia, see d'Hauteserre (2010a and 2008a).
}

\author{
Shima Volume 11 Number 12017 \\ - 69 -
}


personal observation). One government edict is that no building should have more than one floor and traditional housing should be saved to maintain a Polynesian landscape. However, there have been no efforts or incentives to help residents build the traditional way. The department of Cultural Affairs is the sole government organisation that wants to turn to tourism as a tool of economic growth for the territory because it promises to protect the islands' cultural heritage and environment: "Wallis seeks to conserve its original state not yet invaded by globalisation forces" (Interviews, 2009). Polynesian culture in Wallis and Futuna (like Kanak culture in New Caledonia) represents an exception to the efforts of the French state to homogenise the nation (as per specific legal provisions). Polynesian custom has thus continued in Wallis and Futuna, relatively unhindered by colonial impositions. But who decides which cultural heritage will continue to be saved and displayed? It is an important question in Wallis and Futuna as tensions prevail today about the future of this heritage and how it should be preserved (d'Hauteserre, 2015b, 2010c). Infrastructure exists for/in Wallis and Futuna but it is very expensive to reach those islands because of their remoteness. Most of the territory's residents also lack capital and business skills.

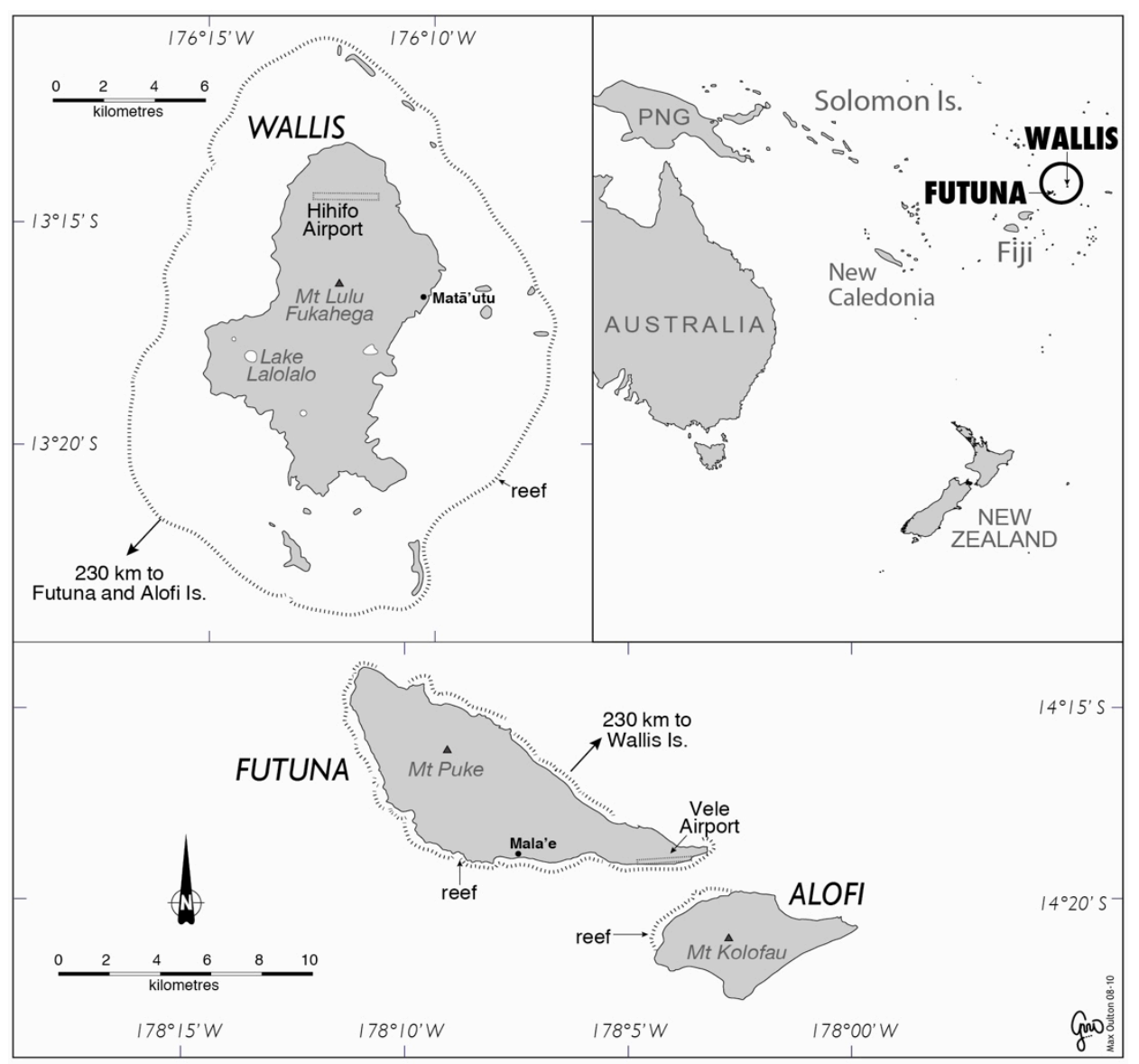

Figure 7 - Map of Wallis and Futuna (by Max Oulton, Cartographer, University of Waikato, 2017)

\section{Shima Volume 11 Number 12017}

-70 - 
Some small-scale efforts are underway to develop the knowledge and skills of local indigenous women (and to teach these to younger generations) and to provide revenue by selling the products as souvenirs for visitors and/or for departing French civil servants. Until now, there has been little in the way of souvenirs besides postcards. Two areas in particular are receiving support: the production of scented oil and the fabrication of tapa, a type of cloth made from tree bark. A machine has been invented to take over the slow and onerous work of beating the bark, which still enables customary production of tapa since one has to apply ancestral knowledge to determine the thickness of the finished product as well as the various steps that follow bark flattening (personal observation; interview of the head of the centre for development of arts and crafts, 2009). A center for Wallis and Futuna arts and crafts was opened in Nouméa on 5 April 2013. In Wallis, an aromatic oil production operation entitled Lolotasi started production in late 2010 (Institut d'Emission, 2014). The perfumed oil, using flowers specific to the territory (so as not to compete with the production based on the Tiare flower of Tahiti), is sold through a pan-Pacific commercial network. An official from the department of Cultural Affairs I interviewed stated that: "we need to open up to the world so they can discover our culture but ceremonies cannot be commoditised" (2009). That is precisely the conundrum today.

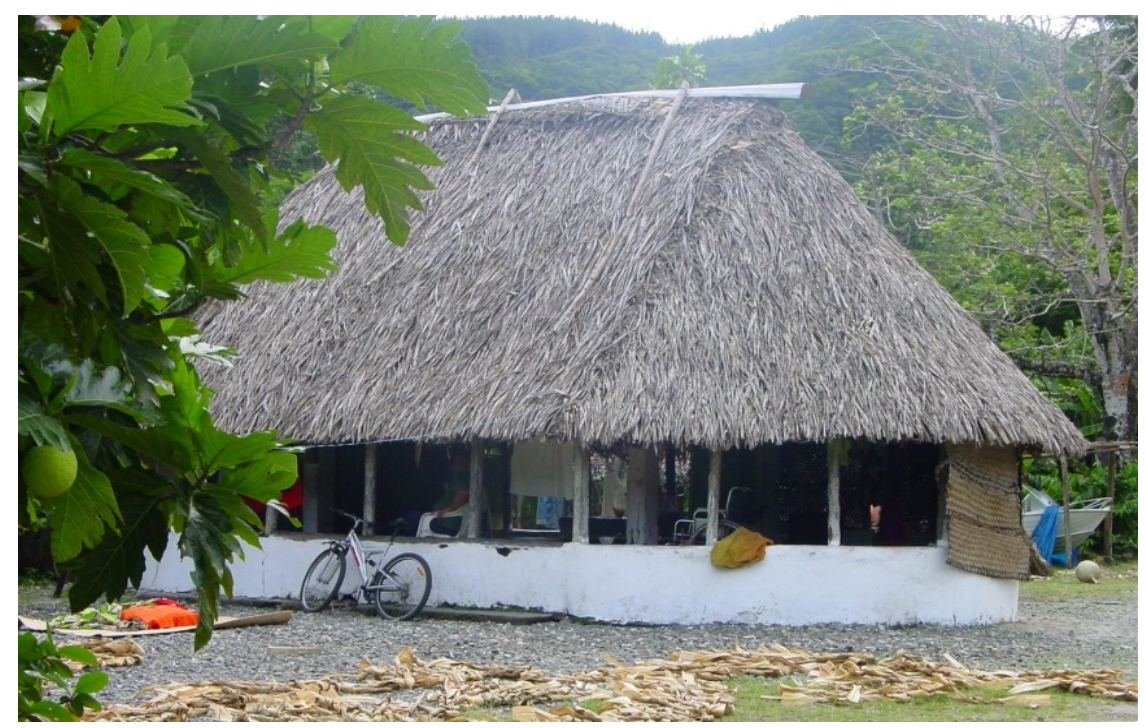

Figure 8 - Traditional house of Wallis and Futuna. Note on the right side of the house, the natural fibre screen that is rolled down at night (as in Samoa). The roof is in traditional material (coconut or pandanus leaves). On the left hand side of the picture, the typical leaves and fruit of the bread fruit tree. On the ground, pieces of bark for tapa making. (Author's photo, 2009).

Many community members' self-esteem has been raised by outside recognition of the value of their culture, their natural resources and their traditional knowledge (Lima, 2008; Weaver, 2010). On the other hand, the majority of residents of the French Pacific prefer modern ways (interviews with residents and cultural organisers 2000-2016; personal observation). They attend local arts and culture festivals but do not participate in them.

\section{Shima Volume 11 Number 12017}

-71 - 


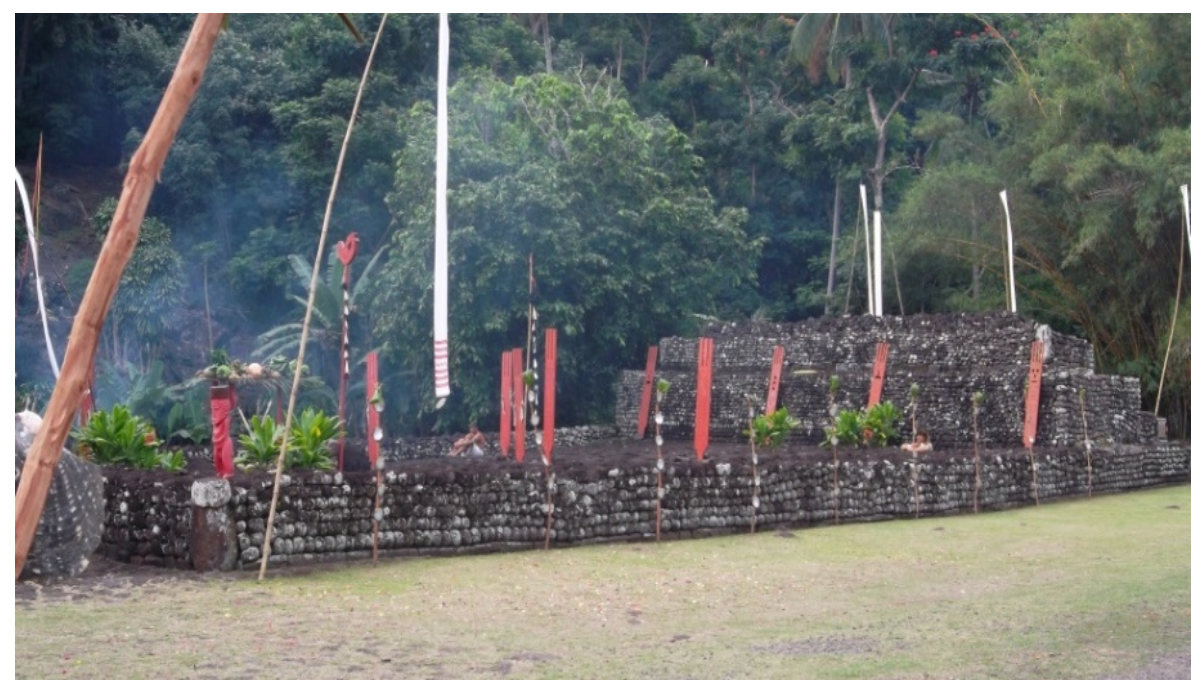

Figure 9 - A reconstructed marae in Tahiti, where ceremonies are represented during Festivals (author's photo, 2012).

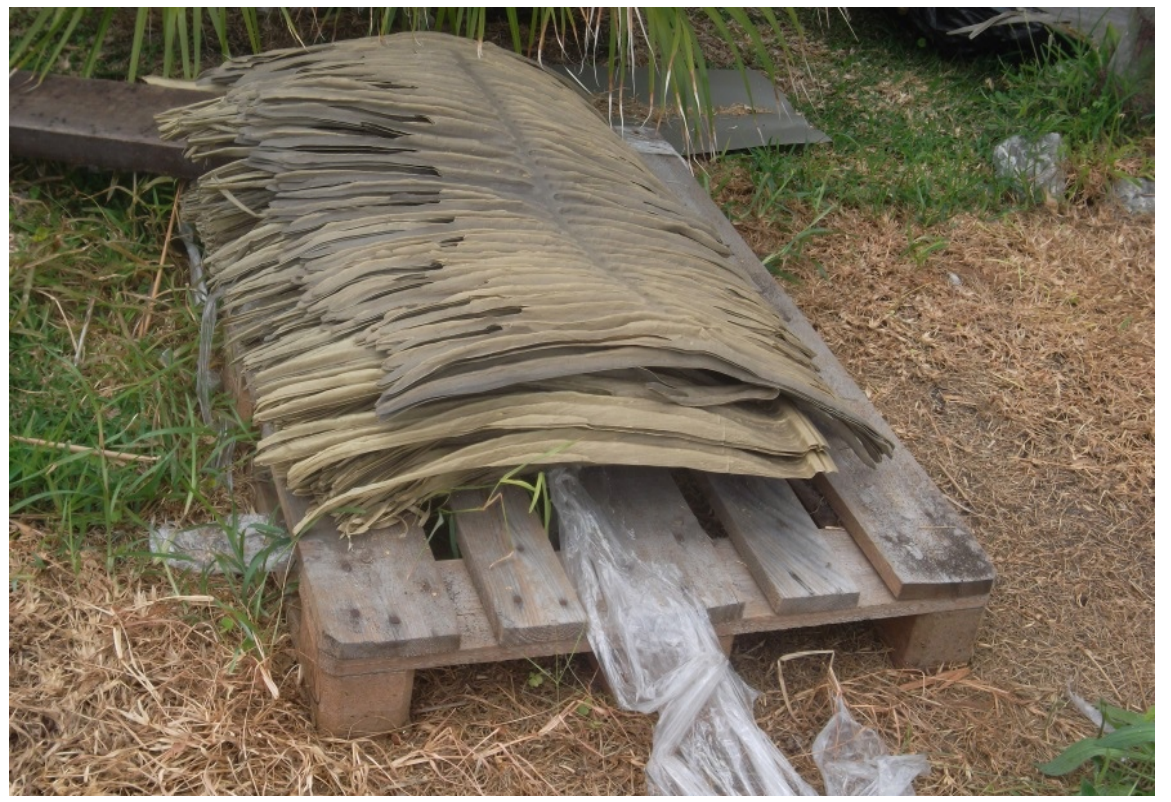

Figure 10 - Fake coconut leaves in plastic (hybridised tradition). The owners of the B\&B in Lifou hope they will last much longer than the natural ones. They should not shelter as many insects either (author's photo 2015). 
Many of the dance groups only have token support from the communities they reside in. Government agencies do not cooperate and sometimes create difficulties for the survival of dance groups (interviews with group leaders and directors of cultural agencies, 2012, 2016) or for the maintenance of traditional housing. Funding is almost non-existent for the reconstruction of marae and especially for organising the reconstructed ceremonies they sometimes host (interviews 2012, 2016). Most residents of remote areas prefer comfortable living conditions and traditional houses (important heritage artefacts for cultural tourists) are increasingly being replaced by modern ones that are easier to aircondition and to maintain. Material for traditional roofs needs to be replaced every ten years but has become very rare. One successful bed and breakfast in Lifou (Loyalty Island Province, New Caledonia) has invested in artificial coconut leaves to cover its constructions (personal observation, 2015). Will indigenous French Pacific hybridised culture vanish like the breadfruit tree? 'Traditional' coconut plantations and the landscapes that were created by that colonial form of production to satisfy colonial markets are most often promoted by tourism even though the traditional tree that provided the basic food in the Island Pacific was/is the breadfruit tree, which is hardly ever depicted in tourist brochures.

\section{Conclusion}

Cultural assets exist because they have been identified and maintained due to their significance for the community where they exist. They become a tourism attraction only once transformed into a product for consumption (Ducros and McKercher, 2015). Could the French Pacific maintain its cultural specificity if it were integrated into the global market through cultural tourism development? One can also wonder whether indigenous residents of the French Pacific will be able to pursue their own agenda(s) rather than those of outside investors or that of the local governments whose attitude remains paternalistic. Whether cultural diversity will (can) survive belongs within the broader question of whither modernity? Is there a future beyond modernity and what might its contours be? In the French Pacific if the intention is to grow the economy based on tourism there must be a reconsideration of the tropes it uses for promotion. Cultural tourism based on local cultural practices will be more appealing to potential tourists, as demonstrated at Eiao in New Caledonia and in other Pacific islands.

Whatever theoretical framing is chosen, though, commodification of culture raises a number of problems. These stagings of indigenous culture cater to fabricated needs (to fit with visitors' habitus) in order to provide the ultimate desirable experience: it exacerbates the desire of visitors to search for new experiences of the exotic 'other' as consumables (Smith, 2003). Tourist culture can then overwhelm the local culture which loses its 'difference' and hence its attractiveness. It also loses meaning for the local residents, outside of its commercial value (Cheer et al, 2013). For tropical island destinations, such stagings are often thought necessary since these islands are ultimately totally substitutable for tourists from developed countries (King and Connell, 1999). Religious rituals, traditional ethnic rites and festivals risk being reduced and sanitised into what has been called "reconstructive ethnicity" (Wearing, 2015) if product development is left in the wrong hands (Mowforth and Munt, 2016). The internal dynamic(s) and complexity of Melanesian and Polynesian cultures, which were veiled by European assumptions as to their timeless nature, could now be further obfuscated and even completely erased for commercial profit. 
That is the main reason cultural tourism should be planned and managed in line with the principles of sustainable tourism. Too often indigenous residents find themselves 'out of place' when their space is appropriated by outside investors for the staging of experiences to maximise tourist pleasure. It puts these two communities and their discourses at odds with each other as they try to share the same space. Indigenous participation should be more than 'staging their presence' as an exotic add-on to capitalist projects (Johnston, 2000; Zeppel, 2006). Or must we accept Desmond's assertion (following Lyotard) that "while desirable, such a world is ultimately incommensurate with and unincorporable into the ongoing 'now' of the tourists' lives and is available only as nostalgia for a time past" (1999: 255)? It would also constrain indigenous identity-building since it can only be anchored in an unchanging past. Images tend to be long-lasting and difficult to modify (Olsen, 20o8; Reisinger and Turner, 2003) but there is no reason to wait to project positive representations of indigenous cultures to the world, which will demonstrate their great variety and hence satisfy this global desire for new consumable experiences. Their variety and wide dispersal can also ensure numbers of visitors will not overwhelm any such destinations, so long as deep sustainability principles remain respected throughout the development and subsequent exploitation of the project.

\section{BIBLIOGRAPHY}

Abbott, D and Pollard, S (2005) Hardship and Poverty in the Pacific, Manila: Asian Development Bank

Altinay, L and Paraskevas, A (2008) Planning Research in Hospitality and Tourism, Amsterdam: Elsevier

Al Wardi, S and Regnault, J-M (2011) Tahiti en crise durable, Papeete: Les Editions de Tahiti

Baldacchino, G (2005) 'The Contribution of 'Social Capital' to Economic Growth: Lessons from Island Jurisdictions', The Round Table v94 n1: 31-46

Brundtland, H (1987) Our Common Future, Oxford: Oxford University Press

Bryman, A (2012) Social Research Methods (4th edition), Oxford: Oxford University Press

Cambodia (2008) 'Sale of the Century', The Guardian Weekly 2nd May: 23-25

Campbell, I (1982) 'Polynesian Perceptions of Europeans in the Eighteenth and Nineteenth Centuries' Pacific Studies v5 n2: 64-8o

Chatterjee, P and Finger, M (2014) The Earth Brokers: Power, Politics and World Development, London: Routledge

Cheer, J.M, Reeves, K.J and Laing, J.H (2013) 'Tourism and Traditional Culture: Land Diving in Vanuatu', Annals of Tourism Research v43: 435-455

Church, A and Coles, T (2006) Tourism, Power and Space, London: Routledge 
Daniel, Y.P (1996) 'Tourism Dance Performances: Authenticity and Creativity', Annals of Tourism Research v23 n4: 780-797

Desmond, J (1999) Staging Tourism: Bodies on Display from Waikiki to Sea World, Chicago: University of Chicago Press

Dewalt, K.M (2011) Participant Observation: A Guide for Fieldworkers (2nd edition), Lanham: Rowan and Littlefield

d'Hauteserre, A-M (2004) 'Postcolonialism, Colonialism and Tourism', in Lew, A, Hall, C.M and Williams A (eds) A Companion to Tourism, Oxford: Blackwell: 235-245

----- (2005) 'Maintaining the Myth: Tahiti and its Islands', in Cartier, C and Lew, A (eds) Seductions of Place, New York: Routledge

----- (2008a) 'New Caledonian Development and the Kanak voice', American Indian Culture and Research Journal v32 n3: 29-49

----- (2008b) 'Paradis extrêmes: restructuration ou perte de culture ? Les Tuamotu et le tourisme', in Dehoorne, $\mathrm{O}$ and Saffache, $\mathrm{P}$ (eds) Mondes insulaires tropicaux: Géopolitique, économie et développement durable, Paris : Ellipses : 127-146

----- (2010a) 'Government Policies and Indigenous Tourism in New Caledonia', Asia Pacific Journal of Tourism Research v15 n3: 285-304

----- (2010b) 'Explaining Antagonism to the Owners of Foxwoods Casino Resort', American Indian Research an Culture Journal, v34 n3: 107-127

----- (2010c) 'Ecotourisme communautaire à Wallis et Futuna : peut-on concilier culture, nature et tourisme?', in Breton J.M (ed) Patrimoine culturel et tourisme alternatif (volume II), Paris: Karthala: 72-89

----- (2011) 'Politics of Imaging New Caledonia', Annals of Tourism Research v38 n2: 38o402

----- (2015a) 'Tourism in the French Pacific', in Pratt, S and Harrison, D (eds) Tourism in the Pacific Islands, London: Routledge: 22-35

----- (2015b) 'Ecotourism, an Option in Small Remote Islands?' Journal of Tourism and Hospitality Research, v16 nı: 72-87

Diamond, H (2008) American Aloha: Cultural Tourism and the Negotiation of Tradition, Honolulu: University of Hawaii Press.

Din, K (1997) 'Indigenisation of Tourism Development: Some Constraints and Possibilities', in Opperman, D (ed) Pacific Rim Tourism, London: CABI: 76-81

Ducros, H and McKercher, B (2015) Cultural Tourism, London: Routledge

Durban, J-F (2005) Le substrat de la tradition en Polynésie française, Paris : L’Harmattan 
Epler Wood, M (2007) 'The Role of Sustainable Tourism in International Development', in Higham, J (ed) Critical Issues in Ecotourism: Understanding a Complex Tourism Phenomenon, Oxford: Elsevier: 158-184

Faberon, J-Y and Postic, J-R (2004) L'Accord de Nouméa, la Loi Organique et autres documents juridiques et politiques de la Nouvelle-Calédonie, Nouméa: Ile de Lumière

Fairclough, N (2013) 'Critical Discourse Analysis and Critical Policy Studies', Critical Policy Studies v7 n2: 177-197

Gay, J-C (2009) Les cocotiers de la France, Paris : Belin

Hardt, M and Negri, A (1998) Empire, Cambridge: Harvard University Press

Hau'ofa, E (1987) 'The New Pacific Society: Integration and Independence', in Hooper, A (ed) Class and Culture in the South Pacific, Suva: Institute of Pacific Studies, University of the South Pacific: 1-12

----- (1994) 'Our Sea of Islands', The Contemporary Pacific v6 nı: 147-161

Heckman, D (2008) A Small World: Smart Houses and the Dream of the Perfect Day, Durham: Duke University Press

Hughes, G (2004) 'Tourism, Sustainability and Social Theory', in Lew, A, Hall, C.M and Williams A (eds) A Companion to Tourism, Oxford: Blackwell: 498-509

Institut Territorial de la Statistique (2008) Les tableaux de l'économie polynésienne, Papeete: Imprimerie Officielle

Institut d'Emission d'Outremer (IEOM) (2014) Rapport, Wallis

Jennings, G (2010) Tourism Research, Milton: John Wiley \& Sons, Australia

Johnston, A (2000) 'Indigenous People and Ecotourism: Bringing Indigenous Knowledge and Rights into the Sustainability Equation, Tourism Recreation Research v25 n2: 89-96

Jovchelovitch, S (2007) Knowledge in Context: Representations, Community and Culture, London: Routledge

Kahveci, G, Ok, and Yylmaz, E (2011) 'Ecotourism and Sustainable Development of Forests and Forest Villagers in Turkey': http://www.fao.org/DOCREP/ARTICLE?WFC/XII/o708-A1 - accessed 18th July 2013

Kerdilès, M (1998) Itinéraire Polynésien, Papeete: Au Vent Des Iles

King, R and Connell, J (1999) Small Worlds, Global Lives - Islands and Migration, London: Pinter

Kirch, P (1986) 'Exchange Systems and Inter-island Contact in the Transformation of an Island Society: the Tikopia Case, in Kirch, P (ed) Island Societies: Archaeological 
Approaches to Evolution and Transformation, Cambridge: Cambridge University Press: $33-41$

Lima, I (2008) Micropolitics in Ecotourism, (unpublished) PhD thesis, University of Waikato, New Zealand

Lyotard, J-F (1988) The Différend: Phrases in Dispute (trans. van den Abbeele, G), Minneapolis: University of Minnesota Press

Mallatrait, C (2009) La France, puissance inattendue au XXIème siècle dans le Pacifique sud, Paris: L'Harmattan.

Mbembe, A (2001) On the Postcolony, Berkeley: University of California Press.

Mission d'Evaluation et de Prospective (200o) Rapport de prospective, Papeete: Présidence du Gouvernement de la Polynésie Française

Mowforth, M and Munt, I (2016) Tourism and Sustainability: Development and New Tourism in the Third World, London: Routledge

Newbury, C (1980) Tahiti Nui - Change and Survival in French Polynesia, 1767-1945, Honolulu: University Press of Hawai'i

Olsen, K (2008) 'The Maori of Tourist Brochures Representing Indigenousness', Journal of Tourism and Cultural Change v6 n3: 161-184

Panoff, M (1970) La terre et l'organisation sociale en Polynésie, Paris: Payot

Pine, B.J and Gilmore, J.H (1999) The Experience Economy, Boston: Harvard Business School Press

Prakash, G (1994) 'Subaltern Studies as Postcolonial Criticism, American Historical Review v99 n5: 1475-149o

Purcell, M (2009) 'Resisting Neoliberalisation: Communicative Planning or Counterhegemonic Movements, Planning Theory v8 n2: 140-165

Reimer, J.K and Walter, P (2013) 'How do you know it when you see it? Community Based Ecotourism in the Cardamom Mountains of South-western Cambodia, Tourism Management v34 n1: 122-132

Reisinger, Y and Turner, L (2003) Cross-cultural Behavior in Tourism: Concepts, Analysis, Oxford: Butterworth

Rofel, L (1997) 'Rethinking Modernity: Space and Factory Discipline in China, in Gupta, A and Ferguson, J (eds) Culture, Power, Place, Durham: Duke University Press: 155-178

Rolett, B (1996) 'Colonisation and Cultural Change in the Marquesas', in Davidson, J, Irwin, G, Leach, F, Pawley, A and Brown, D (eds) Oceanic Culture History. Essays in Honour of Roger Green, Dunedin: New Zealand Journal of Archeology special publication: 531-540 
Schaeffer, F (2001) 'Mythe du retour et de réalité de l'entre-deux. La retraite en France ou au Maroc, Revue Européenne des Migrations Internationales v17 nı : 165-176

Schmitt, B (2003) Customer Experience Management: A Revolutionary Approach to Connecting with your Customers, New York: Wiley

Sem, G (200o) Chroniques Polynésiennes, Papeete: DDOM

Shurmer-Smith, P and Hannam, K (1994) Worlds of Desire, Realms of Power: A Cultural Geography, London: Edward Arnold

Skelton T (2007) 'Islands for the Young: Culture and Development for All - A Commentary on John Connell's 'Islands, Idylls and the Detours of Development', Singapore Journal of Tropical Geography v28 n2: 136-138

Smith, M.K (2003) 'Indigenous Cultural Tourism', in her Issues in Cultural Tourism Studies, London: Routledge: 117-132

Sofield, T.H.B and Tamasese, E (2011) Tourism-led Poverty Reduction Programme for Samoa: Strengthening Linkages between Tourism and Agricultural Sectors, Geneva: United Nations International Trade Centre

Teiawa, T (2001) '"L(o)osing the edge"', The Contemporary Pacific v13 n2: 343-357

Tjibaou, J-M (1996) La présence kanak, Paris: Editions Odile Jacob

Timothy, D.J (2007) Managing Heritage and Cultural Tourism Resources, New York: Ashgate

Tukker, A and Tischner, U (eds) (2006) New Business for Old Europe: Product-service Development, Competitiveness and Sustainability, Sheffield: Greenleaf Publishing Ltd.

Walliman, N (2011) Your Research Project, London: Sage

Wearing, S (2015) 'Commodification', in Cater, C Garrod, B and Low, T (eds) The Encyclopedia of Sustainable Tourism, Wallingford: CABI

Weaver D B (2010) 'Indigenous Tourism Stages and their Implications for Sustainability, Journal of Sustainable Tourism v18 n1: 43-6o

Weaver, D B (2003) The Encyclopedia of Ecotourism, Wallingford: CABI Publishing

Wheat, S (2002) 'Visiting Disaster', Guardian Weekly, June 20-26: 8

Zeppel, H (2006) Indigenous Ecotourism: Sustainable Development and Management, Wallingford: CABI 